\title{
PENINGKATAN HASIL BELAJAR IPA DENGAN MODEL PROBLEM BASED LEARNING BERBANTUAN MEDIA AUDIOVISUAL KELAS IV SD
}

\author{
Sugi Oktari ${ }^{1}$, Henny Dewi Koeswati ${ }^{2}$, Sri Giarti ${ }^{3}$ \\ ${ }^{1}$ Pendidkan Guru Sekolah Dasar, UKSW Salatiga, 292013237@student.uksw.edu \\ ${ }^{2}$ Pendidkan Guru Sekolah Dasar, UKSW Salatiga, dewi@staff.uksw.edu \\ ${ }^{3}$ Pendidkan Guru Sekolah Dasar, UKSW Salatiga, sgiarty@gmail.com
}

\begin{tabular}{l} 
INFO ARTIKEL \\
\hline Riwayat Artikel: \\
Diterima: 25-03-2018 \\
Disetujui: 09-04-2018 \\
\hline Kata Kunci: \\
Problem Based Learning \\
berbantuan media \\
Audiovisual, IPA, Hasil \\
Belajar, Sekolah Dasar \\
Kelas IV
\end{tabular}

\begin{abstract}
ABSTRAK
Problem Based Learning berbantuan media Audiovisual terhadap hasil belajar IPA siswa kelas IV SDN Gondorio 02. Jenis penlitian yang di gunakan adalah penelitian tindakan kelas yang terdiri dari 2 siklus. setiap siklus di lakukan melalui 4 tahap yaitu perencanaan, pelaksanaan, pengamatan, dan refleksi. subjek penelitian ini adalah seluruh siwa kelas IV. Data penelitian diperoleh melalui observasi, dan tes. Data hasil observasi aktifitas guru dan siswa dianalisis dalam bentuk tabel. Data tes hasil belajar siswa dianalisis berdasarkan persentase ketuntasan belajar secara individu dan klasikal kemudian di jabarkan secara deskriptif. Hasil penelitian menunjukan adanya peningkatan persentase hasil belajar siswa pada siklus I dan siklus II. Hasil belajar yang diperoleh siswa kelas IV. Hal ini ditunjukkan dengan hasil belajar siswa pada evaluasi mengacu pada kriteria keberhasilan yang sudah ditentukan yaitu 70. Nilai rata-rata ketuntasan belajar siswa secara klasikal mengalami peningkatan sebesar $83 \%$ pada mata pelajaran IPA, dengan rincian pra siklus ketuntasan $32,7 \%$ dari 7 siswa yang mencapai keberhasilan dengan rata-rata 57,7 , siklus I menjadi $71 \%$ dari 29 siswa yang mencapai keberhasilan dengan rata-rata 72,7 dan menjadi $83 \%$ pada siklus II dari 16 siswa yang mencapai ketuntasan belajar dengan rata-rata 82,7. Berdasarkan hasil yang diperoleh dapat disimpulkan bahwa pembelajaran dengan menggunakan metode Problem Based Learning berbantuan media Audiovisual dapat meningkatkan hasil belajar siswa kelas IV SD Gondorio 02.
\end{abstract}

\begin{abstract}
Problem Based Learning Audiovisual-supported media to the results of science learning grade IV SDN Gondorio 02. Type of research that is used is a classroom action research consisting of 2 cycles. each cycle is done through 4 stages of planning, implementation, observation, and reflection. the subject of this study is all students of class IV. Research data obtained through observation, and test. Observation data of teacher and student activity were analyzed in table form. Data test results of student learning is analyzed based on the percentage of mastery learning individually and classically then described descriptively. The results showed an increase in the percentage of student learning outcomes in cycle I and cycle II. Learning outcomes obtained by grade IV students. This is indicated by the results of student learning on the evaluation refers to the predetermined success criteria that is 70 . Students average grade of completeness in the classroom has increased by $83 \%$ on science subjects, with details of pre-cycle mastery of $32.7 \%$ of 7 students which achieved success with an average of 57.7 , cycle I to $71 \%$ of 29 students who achieved success with an average of 72.7 and became $83 \%$ in cycle // of 16 students who achieve mastery learning with an average of 82.7 . Based on the results obtained can be concluded that the learning by using Problem Based Learning method Audiovisual media aid can improve student learning outcomes grade IV SD Gondorio 02.
\end{abstract}

\section{A. LATAR BELAKANG}

Pada hakikatnya belajar adalah suatu proses usaha yang dapat dilakukan seseorang untuk memperoleh suatu perubahan-perubahan tingkah laku yang baru secara keseluruhan, sebagai hasil pengalamannya sendiri dalam interaksi dengan lingkungan (Slameto 2010). Belajar terjadi karena adanya interkasi stimulus dan respon dan ditandai dengan perubahan tingkah laku. Guru memberikan stimulus atau rangsangan dalam kegiatan pembelajaran berupa pikiran, motivasi kepada siswa. Sedangkan respon dimunculkan oleh siswa dalam pembelajaran berupa gerakan atau tindakan setelah guru memberikan stimulus.

Pembelajaran merupakan proses interaksi antara peserta didik dengan pendidik dan sumber belajar pada 
suatu lingkup lingkaran belajar (Undang-Undang Republik Indonesia Nomor 20 Tahun 2003 Tentang Sistem Pendidikan Nasional pada pasal 1). Pembelajaran adalah suatu usaha untuk membuat peserta didik belajar atau suatu kegiatan untuk membelajarkan peserta didik (Warsita 2008: 85). Sehingga, pembelajaran adalah proses interaksi antara peserta didik dan guru serta sumber belajar yang tujuannya membuat peserta didik belajar atau kegiatan untuk membelajarkan peserta didik sehingga dapat mencapai tujuan yang akan dicapai oleh peserta didik dan pendidik. Pembelajaran dalam proses kegiatan belajar mengajar tidak lepas dari hasil belajar siswa.

Hasil belajar sangat erat dengan belajar atau proses kegiatan pembelajaran.. Hasil belajar adalah perubahan-perubahan yang terjadi pada diri siswa, baik yang menyangkut aspek kognitif, afektif, dan pesikomotor sebagai hasil dari kegiatan belajar ( Susanto 2013: 5). Berdasarkan uraian diatas maka dapat disimpulkan bahwa hasil belajar merupakan perubahanperubahan yang terjadi pada siswa sebagai tingkat keberhasilan dalam mempelajari materi yang ada disekolah melalui tes atau mengenal sejumlah materi pelajaran tertentu yang dinyatakan dalam skor.

Ilmu Pengetahuan Alam berhubungan dengan cara-cara mencari tahu tentang alam secara sistematis, sehingga Ilmu Pengetahuan Alam bukan hanya penguasaan kumpulan sistematis dan Ilmu Pengetahuan Alam tidak hanya penguasaan kumpulan pengetahuan yang berupa fakta-fakta, konsep-konsep atau prinsipprinsip saja, tetapi juga merupakan suatu proses-proses penemuan (Sulistyorini, 2007: 39). Sedangkan menurut Iskandar (2001: 2), IPA merupakan ilmu yang mempelajari peristiwa yang terjadi dialam. Ilmu Pengetahuan Alam merupakan mata pelajaran di SD yang ditujukan agar siswa mempunyai pengetahuan, gagasan dan konsep yang terorganisasi tentang alam disekitar, yang diperoleh dari pengalaman melalui rangkaian proses ilmiah antara lain penyelidikan, penyusunan dan penyajian gagasan-gagasan. Dari beberapa pendapat di atas maka dapat disimpulkan bahwa pembelajaran IPA adalah ilmu yang mempelajari peristiwa-peristiwa yang terjadi di alam dengan melakukan observasi, eksperimentasi, penyimpulan, penyusunan teori agar siswa mempunyai pengetahuan, gagasan dan konsep yang terorganisasi tentang alam sekitar, yang diperoleh dari pengalaman melalui serangkaian proses ilmiah antara lain penyelidikan, penyusunan dan penyajian gagasan-gagasan.

Seperti yang disebutkan dalam pengertian IPA begitu pentingnya suatu pengamatan dan pemecahan masalah dalam mata pelajaran IPA. Dalam proses pembelajaran IPA siswa seharusnya diajarkan tentang bagaimana cara memecahkan suatu masalah. Dengan siswa diajak untuk memecahkan masalah, siswa dapat memahami pengetahuan baru yang akan siswa dapatkan. Tetapi, pada kenyataan pada proses belajar mengajar dikelas, guru hanya memeberikan materi dan belum ada tindak lanjut untuk melibatkan siswa lebih aktif dan kreatif tentang materi yang siswa pelajari secara langsung. Sehingga siswa hanya menerima materi yang disampaikan oleh guru, siswa hanya mendengarkan, mencatat dan menghafal tentang materi yang mereka dapatkan melalui penjelasan guru.

Salah satu contoh dapat dilihat dari observasi awal yang dilakukan di SD Negeri Gondorio 02. Dari hasil pengamatan proses belajar mengajar yang dilakukan oleh guru kelas IV Negeri Gondorio 02 Kecamatan Bergas Kabupaten Semarang terdapat beberapa permasalahan dalam proses pembelajaran IPA, diantaranya siswa masih mengalami kesulitan dalam memahami mata pelajaran IPA Minat siswa terhadap kegiatan belajar masih sangat kurang. Siswa menjadi pasif karena tidak terlibat secara langsung dalam pembelajaran. Akibatnya siswa enggan untuk bertanya dan menjawab pertanyaan dari guru. Hal ini menyebabkan siswa menjadi kurang antusias dalam belajar sehingga berdampak ke hasil belajar siswa. Akibatnya hasil belajar siswa kurang memuaskan dan kurang maksimal.

Dilihat dari observasi awal terdapat beberapa permasalahan dari pembelajaran. Permasalahan pertama, guru mengajar masih menggunakan komunikasi satu arah atau yang sering disebut dengan metode ceramah. Dengan menggunakan metode ceramah selama jam pelajaran berlangsung membuat siswa melakukan hal-hal yang dapat mengganggu kegiatan belajar mengajar yang sedang berlangsung, karena siswa tidak terlibat secara aktif dan langsung dalam pembelajaran tersebut. Akibatnya siswa mencari kesibukan sendiri misalnya : mengganggu teman yang lain, bermain sendiri, dan memikirkan hal-hal diluar jam belajar. Siswa menjadi jenuh karena dalam pembelajaran guru tidak merangsang siswa untuk aktif dan dapat mengeluarkan pendapatnya. Siswa hanya memonton, mendengar, mencatat, dan menghafal. Sehingga siswa menjadi lebih sulit dalam memahami materi yang guru berikan. Permasalahan kedua, kurangnya media pembelajaran yang dipakai oleh guru dalam mengajar. Dengan menggunakan media pemebelajaran, guru dapat merangsang antusias belajar siswa. Dengan menggunakan media belajar yang menarik siswa menjadi senang dalam belajar karena mereka menemuka hal baru dalam pelajaran tersebut.

Untuk mengatasi permasalahan tersebut dapat dilakukan tindakan kelas berupa pembelajaran IPA dengan model pembelajaran kooperatif tipe Problem Based Learning berbantuan media Audiovisual. Model pembelajaran kooperatif melibatkan siswa secara aktif dalam proses pembelajaran. Keberhasilan belajar dari kelompok tergantung pada kemampuan dan aktivitas anggota kelompok, baik secara individual maupun secara kelompok (Slavin dalam Komalasari 2013:62). 
Sehubungan dengan latar belakang masalah, ditemukan permasalahan yaitu terdapat beberapa siswa kelas IV khususnya pada pelajaran IPA yang hasil belajarnya belum mencapai KKM, kurangnya minat belajar siswa dalam mengikuti pembelajaran, dan siswa cenderung pasif saat proses pembelajaran. Dengan demikian, inti masalah penelitian ini sebagai berikut: (1) Bagaimana model Problem Based Learning berbantuan media Audiovisual untuk meningkatkan hasil belajar siswa pada mata pelajaran IPA kelas IV SD Negeri Gondorio 02 Kecamatan Bergas Kabupaten Semarang semester II tahun pelajaran 2017/2018? (2) Apakah model Problem Based Learning berbantuan media Audiovisual dapat meningkatkan hasil belajar siswa pada mata pelajaran IPA kelas IV SD Negeri Gondorio 02 Kecamatan Bergas Kabupaten Semarang semester II tahun pelajaran 2017/2018?

Berdasarkan masalah tersebut, penelitian ini bertujuan untuk : (1) Melalui model Problem Based Learning berbantuan media Audiovisual dapat menjelaskan bagaimana model Problem Based Learning berbantuan media Audiovisual dapat meningkatkan hasil belajar siswa pada mata pelajaran IPA kelas IV SD Negeri Gondorio 02 Kecamatan Bergas Kabupaten Semarang semester II tahun pelajaran 2017/2018, (2) Melalui model Problem Based Learning berbantuan media Audiovisual dapat meningkatkan hasil belajar siswa pada mata pelajaran IPA pada siswa kelas IV SD Negeri Gondorio 02 Kecamatan Bergas Kabupaten Semarang semester II tahun pelajaran 2017/2018. Dari tujuan yang telah dikemukakan tersebut, hasil penelitian inipun diharapkan mampu memberikan manfaat, khususnya pada bidang pendidikan, dengan menjadikan metode pembelajaran inquiry sebagai salah satu metode yang mampu meningkatkan hasil belajar siswa dalam pelajaran IPA.

Mencermati persoalan di atas, peneliti tertarik melakukan penelitian dengan harapan siswa dapat aktif mengikuti kegiatan pembelajaran yang berdampak pada meningkatnya hasil belajar IPA. Subjek yang diteliti adalah siswa kelas IV SD Negeri Gondorio 02 Kecamatan Bergas Kabupaten Semarang semester 2 tahun pelajaran 2017/2018.

\section{B. METODE PENELITIAN}

Penelitian ini merupakan penelitian tindakan kelas (PTK). Penelitian ini di lakukan bertujuan untuk memperbaiki proses pembelajaran di kelas. Penelitian tindakan kelas ini di lakukan di SD Negeri Gondorio 02 Semester II Tahun 2018/2019.
1. Variabel Penelitian dan Definisi Operasional
a. Variabel terikat
Variabel terikat merupakan variabel yang dipengaruhi oleh adanya variabel bebas. Dalam penelitian ini variabel terikat yang dimaksud

penulis adalah meningkatkan hasil belajar siswa kelas IV SD Negeri Gondorio 02 Semester II Tahun 2018/2019 pada pembelajaran IPA (Y).

b. Variabel bebas

Variabel bebas Variabel bebas merupakan variabel yang memberikan pengaruh terhadap variabel terikat (Sugiyono, 2010). Dalam penelitian ini yang dimaksud penulis variabel bebas adalah penerapan model Problem Based Learning berbantuan media audiovisual (X).

Sedangkan definisi operasional sebagai berikut:

a. Model pembelajaran PBL berbantuan media audiovisual adalah pembelajaran yang dilaksanakan untuk membantu guru dalam mengaitkan/menghubungkan materi pembelajaran dengan dunia nyata siswa, serta membantu mendorong siswa dalam menghubungkan pengetahuan yang dimiliki dengan penerapan kehidupan sehari-hari dengan menggunakan media audiovisual sebagai media pembelajaran

b. Keterampilan guru merupakan serangkaian kegiatan dalam proses pembelajaran berkaitan erat dengan kemampuan guru menciptakan kondisi belajar optimal bagi siswa dalam pembelajaran IPA di kelas IV SD dengan model pembelajaran PBL berbantuan media audiovisual yang indikatornya meliputi : 1) memberikan apresepsi; 2) menyampaikan tujuan pembelajaran; 3)memberikan pertanyaan atau masalah; 4) menggunakan media audiovisual; 5) membimbing siswa berpikir secara individual; 6) menyampaikan materi; 7) membimbing jalannya diskusi kelompok; 8) membimbing siswa mempresentasikan hasil diskusi kelompok; 9) memberikan penguatan; 10) melakukan refleksi; 11) memberikan evaluasi.

c. Aktivitas belajar siswa adalah rangkaian kegiatan yang dilakukan siswa dalam mengikuti pembelajaran sehingga menimbulkan perubahan perilaku pada diri siswa. Adapun indikator aktivitas siswa dalam pembelajaran IPA dengan model pembelajaran PBL berbantuan media audiovisual adalah 1) kesiapan siswa dalam mengikuti pelajaran; 2) menanggapi apersepsi; 3) membangun pengetahuan baru melalui media pembelajaran; 4) melakukan pengamatan; 5) melakukan percobaan; 6) mengajukan pertanyaan; 7) berdiskusi kelompok; 8) mempresentasikan hasil di depan kelas; 9) menyimpulkan hasil pembelajaran bersama guru; 10) keaktifan siswa dalam pembelajaran; 11) memperhatikan refleksi; 12) mengerjakan evaluasi.

d. Angket 
Peneliti menggunakan teknik ini untuk mengukur motivasi belajar siswa. Maka dari, peneliti menggunakan teknik angket untuk mendapatkan data dari subjek penelitian tentang kecenderungan motivasi belajar siswa setelah adanya tindakan dengan menerapkan model pembelajaran Problem Based Learning (PBL) berbantuan Audiovisual

\section{Hipotesis Tindakan}

Berdasarkan kerangka berfikir yang telah di uraian, maka hipotesis tindakan yang diajukan didalam penelitian ini adalah meningkatkan hasil belajar ilmu pengetahuan alam pada siswa kelas IV SD Gondorio 02 kecamatan bergas semester II tahun pelajaran 2018/2019. Melalui model Problem Based Learning dapat meningkatkan hasil belajar siswa pada mata pelajaran IPA pada siswa kelas IV SD Gondorio 02 kecamatan bergas semester II tahun pelajaran 2018/2019

\section{HASIL DAN PEMBAHASAN}

\section{Hasil Penelitian}

Hasil belajar siswa kelas IV SD Negeri Gondoriop 02 Kecamatan Bergas Kabupaten Semarang dengan menggunakan model Problem Based Learning berbantuan media Audiovisual dapat dilihat dari kondisi awal, siklus I, dan siklus II. Berdasarkan data yang diperoleh, tampak bahwa hasil belajar siswa mengalami perubahan yang signifikan. Bermula dari kondisi awal, terdapat 7 dari 41 siswa belum mencapai $\mathrm{KKM}(\geq 70)$, pada siklus 1 mengalami kenaikan menjadi (77,8\%) siswa yang tuntas, akan tetapi pada siklus II hasil belajar siswa mengalami peningkatan sehingga terdapat 34 dari 41 siswa yang mampu mencapai $\mathrm{KKM}(\geq 70)$ dengan presentase $88,9 \%$. Pembelajaran yang dilakukan pada siklus 1 menggunakan Standar Kompetensi 7.1 menyimpulkan hasil percobaan bahwa gaya (dorongan dan tarikan dapat mengubah gerak benda.

TABEL 1

HASIL BELAJAR SISWA KELAS IV SEMESTER 2 SD GONDORIO 02 SIKLUS 1

\begin{tabular}{|c|c|c|}
\hline \multirow{2}{*}{ Rentang Nilai } & Pretest & Posttest \\
\cline { 2 - 3 } & F & F \\
\hline $93-100$ & - & 2 \\
\hline $86-92$ & - & 5 \\
\hline $79-85$ & - & 8 \\
\hline $72-78$ & - & 5 \\
\hline $65-71$ & 1 & 9 \\
\hline 0-64 & 40 & 12 \\
\hline Jumlah & 41 & 41 \\
\hline Rata-rata & 40 & 70 \\
\hline Nilai terendah & 15 & 40 \\
\hline Nilai tertinggi & 65 & 100 \\
\hline $\begin{array}{l}\text { Jumlah siswa tidak } \\
\text { tuntas }\end{array}$ & 40 & 12 \\
\hline Jumlah siswa tuntas & 1 & 29 \\
\hline
\end{tabular}

Berdasarkan tabel dan diagram di atas menunjukkan kenaikan nilai rata-rata kelas setelah adanya tindakan dari semula pretes sebesar $40 \%$ naik menjadi $70 \%$ pada postest. Pada nilai rata-rata tertulis akhir siklus I menunjukkan bahwa terdapat $71 \%$ atau 29 dari 41 siswa tuntas belajar, sedangkan $29 \%$ atau 12 dari 41 siswa termasuk dalam kategori tidak tuntas belajar. Hal ini berdasarkan KKM yang telah ditetapkan sekolah yaitu 65. Adapun rata-rata kelas yaitu 70. Ketuntasan belajar klasikal IPA belum mencapai target yang tercantum dalam indikator keberhasilan yaitu sekurangkurangnya $80 \%$ dari ketuntasan belajar klasikal. Untuk itu perlu dilakukan penelitian berikutnya, sehingga peneliti perlu melanjutkan penelitian ke siklus II.

Pelaksanaan Siklus 2 dilakukan pada hari Senin tanggal o9 April 2018. Praktek mengajar pada siklus 2 ini dilaksanakan dengan KD. 7.2 Menyimpulkan hasil percobaan bahwa gaya (dorongan atau tarikan) dapat mengubah bentuk benda.. Tabel 6 memberikan gambaran mengenai hasil pembelajaran pada siklus 2 .

TABEL 2

HASIL BELAJAR SISWA KELAS IV SEMESTER 2 SD GONDORIO O2 SIKLUS 2 NILAI PRETEST DAN POSTTEST IPA SIKLUS II

\begin{tabular}{|c|c|c|}
\hline \multirow{2}{*}{ Rentang Nilai } & Pretest & Posttest \\
\cline { 2 - 3 } & F & F \\
\hline $93-100$ & - & 6 \\
\hline $86-92$ & - & 3 \\
\hline $79-85$ & - & 9 \\
\hline $72-78$ & - & 9 \\
\hline $65-71$ & 2 & 7 \\
\hline 0-64 & 39 & 7 \\
\hline Jumlah & 41 & 41 \\
\hline Rata-rata & 41 & 74 \\
\hline Nilai terendah & 20 & 40 \\
\hline Nilai tertinggi & 70 & 100 \\
\hline $\begin{array}{l}\text { Jumlah siswa tidak } \\
\text { tuntas }\end{array}$ & 39 & 7 \\
\hline
\end{tabular}

Berdasarkan tabel dan diagram di atas menunjukkan kenaikan nilai rata-rata kelas setelah adanya tindakan dari semula pretes sebesar $41 \%$ naik menjadi $74 \%$ pada postest. Pada nilai rata-rata tertulis akhir siklus II menunjukkan bahwa terdapat $83 \%$ atau 34 dari 41 siswa tuntas belajar, sedangkan $17 \%$ atau 7 dari 41 siswa termasuk dalam kategori tidak tuntas belajar. Hal ini berdasarkan KKM yang telah ditetapkan sekolah yaitu 65. Adapun rerata kelas yaitu 76. Hal tersebut sudah mencapai tujuan yang diharapkan yaitu sudah mencapai indikator keberhasilan sekurangkurangnya $80 \%$ siswa tuntas dan mengalami ketuntasan belajar individual sebesar $\geq 65$ dalam pembelajaran IPA meningkat dengan kategori baik, sehingga dapat disimpulkan bahwa siklus II berhasil.

Pada siklus 2 ini pelaksanaan penelitian tindakan kelas dengan menggunakan model pembelajaran Problem Based Learning berbantuan 
media Auiovisual sudah meningkat secara keseluruhan sudah baik karena dalam proses pembelajaran guru mampu menguasai pembelajaran dengan mengatasi masalah-masalah yang terjadi pada siklus 1. Pada pembelajaran siklus 2 ini guru sudah membuat siswa fokus dalam pembelajaran dengan memberikan tugas kepada masing-masing siswa untuk menyimpulkan hasil pembelajaran yang sudah dilakukan dengan cara memberikan lembar kerja kepada masing-masing siswa dan siswa menyimpulkan hasil pembelajaran secara tertulis, dengan demikian siswa benar-benar paham dengan materi yang sudah dipelajari. Selanjutnya, guru selalu memberikan rangsangan kepada siswa berupa pertanyaan-pertanyan sesuai materi yang dipelajari sehingga terjadinya kegiatan tanya jawab antara guru dan siswa yang membuat siswa lebih aktif dalam pembelajaran. Dalam pembelajaran guru selalu menanyakan kepada siswa tentang materi yang belum dipahami oleh siswa sehingga seluruh siswa benar-benar paham tentang materi yang dipelajari. Dengan mengatasi masalah pada siklus 1 yang diterapkan pada siklus 2 pembelajaran menggunakan model Problem Based Learning berbantuan media Audiovisual membuat hasil belajar siswa meningkat pada siklus 2 dibandingkan siklus 1. Karena dapat dilihat dari siklus 2 bahwa 34 siswa kelas IV SDN Gondorio 02 telah mencapai ketuntasan belajar yang sudah ditentukan yaitu KKM $\geq 70$. Sedangkan 7 siswa belum mencapai ketuntasan belajar yang sudah ditentukan. Tetapi pada siklus 2 ini mengalami kenaikan walaupun pelaksanaan pada siklus kedua sudah baik tetapi masih beberapa masalah yang mengganggu diantaranya masih ada beberapa siswa yang pasif dalam proses pembelajaran.

Berikut ini merupakan hasil belajar siswa mata pelajaran IPA pada kondisi awal, siklus 1, dan siklus 2 yang disajikan pada Tabel berikut.

\section{TABEL 3}

DATA HASIL BELAJAR SIKLUS I DAN II

\begin{tabular}{|l|c|c|}
\hline \multicolumn{1}{|c|}{ Data hasil belajar } & Siklus I & Siklus II \\
\hline Nilai Rata-rata & 70 & 74 \\
\hline Nilai Terendah & 40 & 40 \\
\hline Nilai Tertinggi & 100 & 100 \\
\hline Siswa Tuntas Belajar & 29 & 34 \\
\hline $\begin{array}{l}\text { Siswa Tidak Tuntas } \\
\text { Belajar }\end{array}$ & 12 & 7 \\
\hline Persentase Ketuntasan & $71 \%$ & $83 \%$ \\
\hline
\end{tabular}

Berdasarkan tabel dan diagram, terjadi peningkatan hasil belajar dari siklus I sampai siklus II. Pada siklus I memperoleh nilai terendah 40, rata-rata dan nilai tertinggi 100, siswa yang belum tuntas sebanyak 12 dan yang sudah tuntas sebanyak 29, pada siklus I presentase ketuntasan belajar klasikal adalah sebesar $71 \%$ namun harus dilaksanakan siklus II karena belum memenuhi indikator keberhasilan dimana ketuntasan belajar baik sekurang-kurangnya $80 \%$.

Pada siklus II terjadi peningkatan nilai hasil belajar siswa yaitu nilai rata-rata sebesar 76 dengan nilai terendah 45 dan tertinggi 100, pada siklus II siswa yang belum tuntas sebanyak 7 siswa dan siswa yang tuntas dalam belajar 34 siswa, di siklus II ini presentase ketuntasan belajar klasikal mencapai 83\%.

Menurut data di atas kenaikan hasil belajar serta ketuntasan klasikal dari siklus I sampai siklus II, dari 71\% menjadi $83 \%$. Terjadinya kenaikan hasil belajar dikarenakan dalam tahap pembelajaran guru melakukan kegiatan secara terencana dan sistematis.

Berdasar indikator keberhasilan yang ditetapkan, kriteria ideal ketuntasan adalah sekurang-kurangnya $80 \%$. Berdasarkan nilai belajar siswa pada siklus I menunjukkan bahwa presentase ketuntasan belajar klasikla belum mencapai 80\%. Hal ini ditunjukkan dari ketuntasan yang dicapai hanya $71 \%$ dengan jumlah siswa yang tuntas sebanyak 29 dari 41 siswa. Setelah dilaksanakan siklus II menunjukkan bahwa presentase ketuntasan siswa mencapai $83 \%$ dengan jumlah siswa yang tuntas belajar sebanyak 34 dari 41 siswa

Pada penelitian menggunakan media pembelajaran Problem Based Learning berbantuan media Audiovisual ini tidak hanya hasil belajar saja yang meningkat, akan tetapi sikap siswa dalam mengikuti pembelajaran juga meningkat. Sebelum dilakukan penelitian selama mengikuti pembelajaran siswa kurang aktif, kurang berani mengungkapkan pendapat, dan kurang antusias dalam mengikuti pembelajaran. Selain itu, dalam menyampaikan materi guru belum menggunakan model pembelajaran yang bervariasi. Akan tetapi setelah dilaksanakan pembelajaran menggunakan Problem Based Learning Berbantuan media Audiovisual ternyata dapat meningkatkan hasil belajar siswa karena model pembelajaran ini siswa dituntut aktif untuk memecahkan yang dihadapi, memiliki sikap disiplin dan kegiatan bekerjasama menyatukan pikiran sehingga semua siswa paham dengan materi yang dipelajari. Sehingga akan melatih siswa untuk aktif, melatih siswa untuk berpikir kritis, berani mengemukakan pendapatnya maupun idenya, dan memiliki sikap tanggung jawab terhadap tugasnya. Hal ini juga berdampak pada hasil belajar siswa karena siswa akan lebih memahami materi yang diajarkan oleh guru. Selain itu, guru juga hanya berperan sebagai pembimbing dan fasilitator karena guru bukan satusatunya sumber ilmu dan pengetahuan. Berdasarkan hasil penelitian yang dijelaskan diatas, maka model pembelajaran Problem Based Learning Berbantuan media Audiovisual memberikan pengaruh pada peningkatan kognitif siswa. Hal ini sesuai dengan aliran kognitif yang mendefinisikan pembelajaran sebagai cara guru memberikan kesempatan kepada siswa untuk berpikir agar mengenal dan memahami sesuatu yang sedang dipelajari (Darsono dalam Hamdani, 2010:23). 
Peningkatan hasil belajar dan perubahan sikap belajar yang dialami siswa merupakan kelebihan dari penerapan model pembelajaran Problem Based Learning Berbantuan media Audiovisual. Selain mempunyai kelebihan, tentu juga mempunyai kekurangan dalam penerapannya. Kekurangan tersebut dialami pada proses pembelajaran karena masih adanya siswa yang masih cenderung mencari kesibukan sendiri dan mengobrol hal-hal diluar materi saat berlangsungnya kegiatan belajar, Beberapa siswa masih kurang konsentrasi dalam mengikuti pelajaran, siswa masih pasif dalam kegiatan pembelajaraan, ada beberapa siswa yang lambat dalam menerima materi, Namun, kekurangan tersebut dapat diatasi oleh guru pada kegiatan belajar pada siklus 2 dengan cara guru membimbing siswa untuk selalu fokus dalam pembelajaran karena dalam setiap akhir pembelajaran guru memberikan tugas kepada masing-masing siswa menyimpulkan hasil pembelajaran. Selanjutnya, untuk mengatasi siswa yang masih pasif dalam kegiatan pembelajaran guru selalu memberikan rangasangan berupa pertanyaan kepada siswa sehingga siswa dapat merespon rangsangan yang diberikan oleh guru sehingga siswa menjadi lebih aktif dalam pembelajaran. Selanjutnya untuk mengatasi siswa yang lambat dalam menerima materi guru memberikan perlakuan khusus kepada siswa tersebut seperti menanyakan materi yang belum di pahami. dengan menggunakan media Audiovisual siswa lebih mudah dalam belajar karena informasi-informasi yang didapatkan dicatat dengan berdasarkan pemetaan pikiran-pikiran sehingga siswa lebih mudah dalam mempelajari kembali materi yang sudah dapatkan. Pada penggunaan media Audiovisual siswa harus sekreatif mungkin dalam mencatat informasi yang baru didapatkan. Penulisan dengan Audiovisual pemetaan-pemetaan pikiran harus jelas dan menarik, semakin jelas dalam memetakan pikiran maka semakin mudah untuk dipahami, maka dari itu siswa lebih mudah untuk memahami sehingga siswa paham dengan materi baru yang disampaikan, hal itu berdampak pada hasil belajar siswa menjadi lebih baik. Pada peningkatan siklus 2 masih terdapat 2 siswa yang belum lulus KKM, hal itu disebabkan karena kedua siswa itu lambat dalam menerima materi belajar sehingga kedua siswa tersebut perlu adanya bimbingan khusus dalam memberikan materi pembelajaran. Solusi untuk mengatasi siswa yang lambat dalam menerima pelajaran adalah: guru selalu bertanya tentang materi yang belum dipahami siswa dalam setiap langkah pembelajaran, memberikan perlakuan khusus kepada siswa tersebut, siswa yang lambat dalam menerima pelajaran dikumpulkan menjadi satu deret tempat duduk. Dengan seperti itu setiap akhir penyampaian materi guru menjelaskan kembali pada siswa-siswa yang lambat dalam menerima materi yang sudah tergabung menjadi satu. Guru juga mudah dalam mengontrol siswa yang belum benar-benar paham dengan materi tersebut.
Berdasarkan pembahasan dan penjelasan mengenai model pembelajaran PBL berbantuan permainan ular tangga, penulis merumuskan implikasi penelitian seperti di bawah ini:

\section{Implikasi Penelitian}

Implikasi penelitian ini yaitu adanya peningkatan kualitas pembelajaran IPA yang meliputi keterampilan guru, aktivitas siswa, dan hasil belajar menggunakan model pembelajaran PBL berbantuan media audiovisual pada siswa kelas IV SDN Gondorio 02. Yang meliputi implikasi teoritis, praktis dan paedagogis.

\section{a. Implikasi Teoritis}

Secara teoritis implikasi dari penelitian ini yaitu keterkaitan antara hasil penelitian dengan teoriteori yang digunakan oleh peneliti. Penelitian ini membuka wawasan bagi guru terhadap model pembelajaran pbl berbantuan media audiovisual mampu meningkatkan keterampilan guru dalam mengajar terutama dalam hal memotivasi dan memfasilitasi siswa dalam melakukan penyelidikan. Hal ini sesuai dengan pendapat Sutikno (2010) bahwa kedudukan guru mempunyai arti penting dalam pendidikan mengingat tugas serta tanggung jawab mencerdaskan siswanya.

Dalam penelitian ini membuktikan bahwa penerapan model pembelajaran PBL berbantuan media audiovisual dalam pembelajaran IPA dapat meningkatkan kualitas pembelajaran yang meliputi: keterampilan guru, aktivitas siswa, dan hasil belajar.

\section{b. Implikasi Praktis}

Implikasi praktis dalam penelitian ini berkaitan dengan hasil penelitian terhadap proses pelaksanaan pembelajaran. Penerapan model pembelajaran PBL berbantuan media audiovisual dalam pembelajaran IPA dibuat menarik dengan menggunakan media audiovisual yang dapat dikaitkan dengan situasi dunia nyata siswa agar dapat membantu siswa dalam proses pembelajaran.

Penerapan model pembelajaran PBL berbantuan media audiovisual dalam pembelajaran IPA membantu guru dalam meningkatkan proses pembelajaran di kelas, selain itu dapat meningkatkan keterampilan dasar mengajar guru. Setelah diberi pembelajaran IPA dengan menerapakan model pembelajaran PBL berbantuan media audiovisual, siswa menjadi lebih aktif, dan guru selalu mendorong siswa untuk berlatih berpikir kritis, dengan tindakan tersebut dapat meningkatkan hasil belajar siswa, sehingga model pembelajaran PBL berbantuan media audiovisual cocok untuk diterapkan di SD khususnya kelas tinggi karena dapat melatih keterampilan berpikir siswa.

Berdasarkan pengamatan selama proses pembelajaran, didapatkan hasil bahwa keterampilan guru mengalami peningkatan pada setiap siklusnya. Hal tersebut dapat dilihat dari 
tabel pada tiap siklusnya. Pada siklus 1 skor keterampilan guru diperoleh hasil 27,5 dengan kategori baik. Pada siklus II mengalami peningkatan menjadi 38 dengan kategori sangat baik. Berdasarkan pengamatan aktivitas siswa selama proses pembelajaran juga mengalami peningkatan pada setiap siklusnya. Hal tersebut dapat dilihat dari tabel pengamatan aktivitas siswa. Siklus I skor perolehan 30,05 dengan kategori baik, pada siklus II meningkat menjadi 32,7 dengan kategori baik. Berdasarkan hasil tes pada setiap siklusnya. Pada siklus I diperoleh nilai rata-rata 74,84 dengan ketuntasan belajar klasikal 71\%, pada siklus II diperoleh rata-rata 76 dengan ketuntasan belajar klasikal 83\%.

Berdasarkan hal tersebut, penelitian ini dapat dijadikan salah satu referensi dan alternative pilihan bagi guru yang ingin menggunakan model pembelajaran PBL berbantuan media audiovisual dalam melaksanakan pembelajaran pada mata pelajaran yang lain sehingga keterampilan guru, minat belajar siswa, dan hasil belajar siswa meningkat.

\section{c. Implikasi Paedagogis}

Implikasi paedagogis dalam penelitian ini merupakan keterkaitan antara hasil penelitian dengan implikasi sebagai guru. Dengan menerapkan model pembelajaran PBL berbantuan media audiovisual dapat meningkatkan profesionalisme guru menciptakan pembelajaran inovatif, kreatif, menyenangkan sehingga kualitasnya dapat meningkat. Guru dilatih bersikap kreatif, berpikir kritis menyediakan media ataupun alat peraga menarik sesuai materi untuk membangun pengetahuan serta pertanyaan bersifat kritis untuk mengembangkan rasa ingin tahu siswa. Melalui kegiatan inkuiri, masyarakat belajar, pemodelan, guru bertindak sebagai fasilitator serta motivator yang membimbing siswa belajar secara mandiri untuk mencari, menemukan pengetahuan baru berdasarkan pengamatan atau percobaan, menanamkan rasa kerjasama, tanggung jawab, saling membantu, menghargai pendapat antar siswa, menumbuhkan rasa percaya diri, serta semangat belajar. Selain itu, guru dapat melakukan penilaian terhadap proses dan hasil sehingga tujuan pembelajaran dapat tercapai secara optimal.

Dengan demikian dapat disimpulkan bahwa model pembelajaran PBL berbantuan media audiovisual dalam pembelajaran IPA pada siswa kelas IV SDN Gondorio 02 dapat digunakan sebagai solusi bagi para pendidik dalam peran mengajar dibuktikan dengan penelitian ini telah mampu memberikan kontribusi positif bagi peningkatan keterampilan guru, kegiatan belajar siswa, dan hasil belajar.

\section{SIMPULAN DAN SARAN}

Berdasarkan penelitian yang telah dilaksanakan dan hasil analisis data yang diperoleh dari siklus I dan siklus II, dapat diambil kesimpulan berikut:

1. Penerapan model Problem Based Learning berbantuan media Audiovisual dapat meningkatkan hasil belajar pada siswa kelas IV SD Negeri Gondorio 02 kecamatan Bergas Kabupaten Semarang melalui langkah-langkah sebagai berikut: a) Orientasi siswa pada situasi masalah dengan cara guru menjelaskan tujuan pembelajaran dan memotivasi siswa terlibat dalam aktivitas pemecahan masalah. b) Mengorganisasi siswa untuk belajar dengan cara guru membantu siswa mendefenisikan dan mengorganisasikan tugas belajar yang berhubungan dengan pemecahan masalah secara berkelompok. c) Membimbing penyelidikan individual maupun kelompok dengan cara guru mendorong siswa untuk mengumpulkan informasi yang sesuai melalui diskusi kelompok dan masingmasing siswa didorong untuk mengemukakan pendapatnya. d) Mengembangkan dan menyajikan hasil karya: guru membantu siswa dalam merencanakan dan menyiapkan karya dengan cara masing-masing melakukan presentasi tentang hasil diskusi, selain itu kelompok lain menanggapinya. e) Menganalisa serta mengevaluasi proses pemecahan masalah dengan cara melaukan refleksi pada setiap akhir pembelajaran, masing-masing siswa ditugaskan untuk menyimpulkan materi yang sudah dipelajari.

2. Penerapan model Problem Based Learning berbantuan media Ausiovisual pada pembelajaran IPA dapat meningkatkan hasil belajar siswa kelas IV SD Negeri Gondorio 02 Kecamatan Bergas Kabupaten Semarang tahun ajaran 2017/2018. Hal tersebut ditunjukkan dengan peningkatan hasil belajar dari siklus I sampai siklus II. Pada siklus I memperoleh nilai terendah 40 , rata-rata dan nilai tertinggi 100, siswa yang belum tuntas sebanyak 12 dan yang sudah tuntas sebanyak 29, pada siklus I presentase ketuntasan belajar klasikal adalah sebesar $71 \%$ namun harus dilaksanakan siklus II karena belum memenuhi indikator keberhasilan dimana ketuntasan belajar baik sekurang-kurangnya $80 \%$.

3. Pada siklus II terjadi peningkatan nilai hasil belajar siswa yaitu nilai rata-rata sebesar 76 dengan nilai terendah 45 dan tertinggi 100, pada siklus II siswa yang belum tuntas sebanyak 7 siswa dan siswa yang tuntas dalam belajar 34 siswa, di siklus II ini presentase ketuntasan belajar klasikal mencapai $83 \%$. 
Berdasarkan hasil analisis data dan kesimpulan dari penelitian ini, maka peneliti memberikan saran sebagai berikut.

a. Bagi guru. Penelitian menemukan bahwa penggunaan model pembelajaran Problem Based Learning berbantuan media Audiovisual terbukti mampu meningkatkan hasil belajar dan sikap dan keaktifan siswa dalam kelas. Oleh karena itu penelitian menyarankan agar guru lain menerapkan model pembelajaran Problem Based Learning berbantuan media Audiovisual untuk meningkatkan pembelajaran. Model pembelajaran Problem Based Learning berbantuan media Audiovisual yang sudah diujikan disekolah bisa menjadi referensi bagi guru lain untuk menerapkannya pada materi dan mata pelajaran selain IPA.

Untuk menggunakan model pembelajaran Problem Based Learning berbantuan media Audiovisual ini sebaiknya guru menggunakan langkah langkah sebagai berikut : a) Orientasi siswa pada situasi masalah dengan cara guru menjelaskan tujuan pembelajaran dan memotivasi siswa terlibat dalam aktivitas pemecahan masalah. b) Mengorganisasi siswa untuk belajar dengan cara guru membantu siswa mendefenisikan dan mengorganisasikan tugas belajar yang berhubungan dengan pemecahan masalah secara berkelompok. c) Membimbing penyelidikan individual maupun kelompok dengan cara guru mendorong siswa untuk mengumpulkan informasi yang sesuai melalui diskusi kelompok dan masing-masing siswa didorong untuk mengemukakan pendapatnya. d) Mengembangkan dan menyajikan hasil karya: guru membantu siswa dalam merencanakan dan menyiapkan karya dengan cara masing-masing melakukan presentasi tentang hasil diskusi, selain itu kelompok lain menanggapinya. e) Menganalisa serta mengevaluasi proses pemecahan masalah dengan cara melaukan refleksi pada setiap akhir pembelajaran, masingmasing siswa ditugaskan untuk menyimpulkan materi yang sudah dipelajari. Tahap tahap tersebut membuat siswa lebih aktif dalam pembelajaran.

b. Bagi sekolah. Sekolah sebagai lembaga pendidikan dan lembaga sosisal sebaiknya lebih mengembangkan model-model pembelajaran yang inovatif sehingga dapat memotivasi siswa untuk lebih tertarik dalam mengikuti proses pembelajaran.

c. Bagi siswa. Dengan penggunaan model Problem Based Learning berbantuan media Ausiovisual maka siswa lebih tertarik mengikuti pembelajaran dan dapat berpikir lebih kreatif sehingga hasil belajar siswa dapat meningkat. d. Bagi Peneliti Lain. Dalam tindakan penelitian sebaiknya peneliti memilih observer yang kompeten dalam melakukan observasi.

\section{UCAPAN TERIMA KASIH}

Penulis mengucapkan terima kasih kepada semua pihak yang telah membantu dalam proses penelitian, khususnya guru dan siswa kelas IV SDN Gondorio 02.

\section{DAFTAR RUJUKAN}

[1] Departemen Pendidikan Nasional. 2005. Undang-Undang No. 20 Tahun 2003, Tentang Sistem Pendidikan Nasional. Jakarta: Depdiknas

[2] Hamdani. 2011. Strategi Belajar Mengajar. Bandung: Pustaka Setia

[3] Iskandar, Srini M.. 2001. Pendidikan IPA II. Jakarta ; Depdikbub. Dirjen Dikti Proyek Pembinaan Tenaga Kerja.

[4] Komalasari, Kokom. 2013. Pembelajaran Kontekstual Konsep dan Aplikasi. Bandung: PT Refika Aditama

[5] Nurhadi, dkk. 2009. Pembelajaran kontekstual dan penerapannya dalam KBK. Malang: Universitas Negeri Malang

[6] Putra, Nusa. 2013. Metode Penelitian Kualitatif Manajemen. Jakarta: PT. Raja Grafindo Persada

[7] Slameto. 2010. Belajar dan Faktor - Faktor yang Mempengaruhinya. Jakarta: Rineka Cipta.

[8] Sulistyorini, S. 2007. Model Pembelajaran IPA Sekolah Dasar dan Penerapannya dalam KTSP. Semarang: Tiara Wacana

[9] Suprihatiningrum, J. 2013. Strategi Pembelajaran Teori dan Aplikasi. Cetakan pertama. Ar-Ruz Media. Yogyakarta.

[10] Susanto, Ahmad. 2013 Teori Belajar dan Pembelajaran di Sekolah Dasar. Jakarta: Kencana Prenada Medi Group

[11] Trianto, 2011, Model Pembelajaran Terpadu Konsep,Strategi Dan Implementasinya Dalam Kurikulum Tingkat Satuan Pendidikan (KTSP), Jakarta : Bumi Aksara

[12]Warsita, Bambang. 2008. Teknologi Pembelajaran Landasan \& Aplikasinya. Jakarta: Rineka Cipta.

\section{PROFIL PENULIS UTAMA}

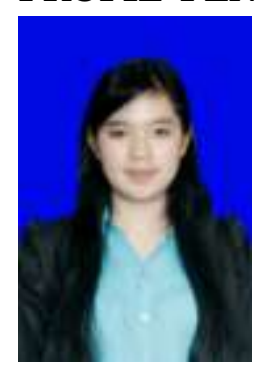

Penulis bernama lengkap "SUGI OKTARI". Lahir di Dusun Kambangan kecamatan bergas kabupaten semarang Provinsi Jawa Tengah pada tanggal 18 Oktober 1994 dari pasangan kaeni dan Kalimen. Penulis adalah anak tiga dari 3 bersaudara. Pendidikan sekolah dasar dimulai dari SD Gondorio 02 pada tahun 2000 - 2007. Setelah itu melanjutkan pendidikan sekolah menengah ke MTS Nurul ikhlas bekasi pada tahun 2007- 2010 dan terakhir di SMA N 13 Bekasi pada tahun 2010 - 2013. Kemudian penulis melanjutkan studi ke perguruan tinggi Universitas Kristen Satya Wacana Salatiga FKIP PGSD pada tahun 2013.

Kritik, saran, maupun hal-hal yang berkaitan dengan kelanjutan atau pengembangan dari hasil penelitian ini bisa dikirim ke email penulis di: oktarindut@gmail.com. 